\title{
Pembuatan Aplikasi Game Edukasi Asmaul Husna Berbasis Android
}

\author{
Novaria Nusantara ${ }^{a}$, Rudy Cahyadi, $M . T^{b}$ \\ a Politeknik Negeri Media Kreatif Jakarta, Jalan Srengseng Sawah, Jagakarsa, Jakarta 12640 a \\ b Politeknik Negeri Media Kreatif Jakarta, Jalan Srengseng Sawah, Jagakarsa, Jakarta 12640 b
}

\begin{tabular}{l} 
INFORMASI ARTIKEL \\
\hline Diterbitkan Online: 31 Juli 2019
\end{tabular}

Diterbitkan Online: 31 Juli 2019

\section{KATA KUNCI}

Game, Asmaul Husna, TPA

\section{KORESPONDENSI}

E-mail Mahasiswa : novarianusantara

$91 @$ gmail.com

E-mail Dosen Pembimbing Pertama:

masrudyc@gmail.com

\section{A B $\mathbf{S} \mathbf{T} \mathbf{R}$ A $\mathbf{C}$ T}

Asmaul Husna adalah nama-nama Allah yang terbaik yang menunjukkan keagungan dan kesempurnaan-Nya yang berjumlah sembilan puluh sembilan. Mempelajari Asmaul Husna sejak usia dini dilakukan agar anak dapat lebih mencintai Allah, sehingga anak memiliki akhlak yang baik karena selalu ingat kepada Allah. TPA adalah salah satu lembaga pendidikan non-formal yang mengenalkan anak pada pembelajaran Asmaul Husna. Metode konvensional yang kurang interaktif masih mendominasi sebagian besar TPA yang kadang menyebabkan siswa mudah bosan. Dengan adanya inovasi teknologi dalam dunia pendidikan, maka akan membantu pembelajaran murid, seperti media pembelajaran menggunakan game. Game edukasi dapat mendorong siswa untuk belajar aktif dan kreatif, sehingga belajar menjadi terasa menyenangkan.

Asmaul Husna are the best names of Allah that show His majesty and perfection which numbered ninety-nine. Studying Asmaul Husna from an early age is done so that children can love God more, so that children have good morals because they always remember God. TPA is one non-formal educational institution that introduces children to Asmaa'ul Husna learning. The less interactive conventional methods still dominate most of the TPAs which sometimes cause students to get bored easily. With the existence of technological innovation in the world of education, it will help student learning, such as learning media using games. Educational games can encourage students to learn actively and creatively, so learning becomes fun.

\section{PENDAHULUAN}

Asmaul Husna adalah nama-nama Allah yang terbaik yang menunjukkan keagungan dan kesempurnaan-Nya yang berjumlah sembilan puluh sembilan (Tafsir Qs.Al-A'raf/7:180). Diriwayatkan dari sebuah hadist bahwa Abu Hurairah r.a, berkata Rasulullah SAW telah bersabda: "Sesungguhnya Allah SWT mempunyai sembilan puluh sembilan nama, seratus kurang satu, barang siapa yang menghimpunnya, maka ia akan masuk surga" (HR. Bukhori). Oleh sebab itu kita sebagai umat islam perlu untuk mengenal dan mempelajari Asmaul Husna sejak usia dini. Hal ini dilakukan agar anak dapat lebih mencintai Allah, sehingga anak memiliki akhlak yang baik karena selalu ingat kepada Allah.
Pengenalan Asmaul Husna pada anak sudah dikenalkan dalam pendidikan formal maupun non formal. Salah satu pendidikan non formal yang sudah mengenalkan anak pada Asmaul Husna adalah TPA, namun TPA saat ini masih di dominasi oleh metode konvensional seperti buku atau lembaran kertas yang memiliki beberapa kekurangan seperti fisik yang mudah rusak dan kurang interaktif yang menyebabkan siswa mudah bosan. Selain itu rasa malas membaca dan bahkan tidak dapat membaca bagi siswa TPA yang rata-rata usianya adalah 4-12 tahun menjadi faktor lain bahwa media pembelajaran secara konvensional ini kurang interaktif, sehingga diperlukan sebuah inovasi berupa aplikasi pembelajaran Asmaul Husna yang dapat meningkatkan minat 
baca, mendengarkan, dan menghafal Asmaul Husna pada siswa TPA(Farid, Darmawan, Anwari, 2017).

Sebagai sample, dilakukan wawancara pada salah satu TPA yang berada di Kota Bogor, yaitu TPA Cabe Rawit Masjid Darussalam. TPA ini masih menggunakan metode pembelajaran secara konvensional, ditemukan beberapa kendala yang dialami TPA ini, yaitu persentase kehadiran siswa yang rendah yang menyebabkan program menghafal Asmaul Husna sedikit terhambat. Target-target yang telah direncanakan sebelumnya tidak terlaksana dengan baik. Contohnya seperti, target usia 1012 tahun yang seharusnya sudah mampu menghafal 99 Asmaul Husna namun karena persentase kehadirannya kurang, target ini tidak tercapai dengan baik (Trio, 2020).

Dengan melihat latar belakang tersebut, akan dibuat sebuah aplikasi pembelajaran Asmaul Husna berbasis Android.

\section{TINJAUAN PUSTAKA}

\subsection{Game Edukasi}

Kata "game" berasal dari bahasa Inggris yang dalam bahasa Indonesia memiliki arti "permainan". Menurut Kamus Besar Bahasa Indonesia (KBBI), permainan memiliki arti sebagai sesuatu yang dipakai untuk bermain, barang atau sesuatu yang dipermainkan, yang artinya permainan adalah sebuah alat yang digunakan untuk bermain serta suatu cara atau aturan yang digunakan bermain.

Game edukasi merupakan sebuah permainan yang dibuat dan dirancang khusus untuk dijadikan sebuah media yang digunakan untuk mengajar orang melalui materi yang berisikan suara, teks, gambar, video, dan animasi, yang pokok materinya membahas suatu subjek tertentu, yang memiliki tujuan untuk dapat memperluas konsep, memberikan pemahaman yang lebih baik dari materi yang mengajarkan sebuah peristiwa sejarah maupun budaya, dan dapat pula mengajarkan pengguna dari game edukasi ini dengan baik, karena mereka dapat bermain sambil belajar dengan mudah (Wijaya, 2017).

Ada beberapa kelebihan dari game edukasi dibandingkan dengan metode pembelajaran konvensional. Salah satu kelebihan utama game edukasi adalah pada visualisasi dari permasalahan nyata. Massachussets Insitute of Technology (MIT) berhasil membuktikan bahwa game sangat berguna untuk meningkatkan logika dan pemahaman pemain terhadap suatu masalah melalui proyek game yang dinamai Scratch. Berdasarkan hasil penelitian sebelumnya, tidak diragukan lagi bahwa game edukasi dapat menunjang proses pendidikan (Clark, R. E, 2006).

Game edukasi unggul dalam beberapa aspek jika dibandingkan dengan metode pembelajaran konvensional. Salah satu keunggulan yang signifikan adalah adanya animasi yang dapat meningkatkan daya ingat sehingga anak dapat menyimpan materi pelajaran dalam waktu yang lebih lama dibandingkan dengan metode pengajaran konvensional (Donald Clark, 2006).

\subsection{Aplikasi Berbasis Android}

Android adalah sistem operasi berbasis Linux yang digunakan untuk telepon seluler (mobile) seperti smartphone dan computer tabled (PDA). Android juga menyediakan platform terbuka bagi para pengembang untuk menciptakan aplikasi mereka sendiri yang akan digunakan untuk berbagai macam piranti gerak (Murya, 2014).

Android memiliki beberapa versi sesuai dengan perkembangannya. Pada saat ini tingkatan android dari tingkatan A sampai N. Setiap versi memiliki level API. Berikut ini beberapa versi android (Techijau, 2015).

Tabel 1 Sejarah Versi OS Android

\begin{tabular}{|c|c|c|c|}
\hline No & Android Versi & $\begin{array}{c}\text { Tanggal } \\
\text { Rilis }\end{array}$ & Fitur \\
\hline 1 & $\begin{array}{l}\text { Android versi } \\
4.1 \text { (Jelly Bean } \\
\text { ) }\end{array}$ & 9 Juli 2012 & $\begin{array}{l}\text { Android Jelly Bean } \\
\text { yang diluncurkan } \\
\text { pada acara Google } \\
\text { I/O membawa } \\
\text { sejumlah } \\
\text { keunggulan dan fitur } \\
\text { baru. Adapun } \\
\text { penambahan fitur } \\
\text { baru diantaranya } \\
\text { yaitu meningkatkan } \\
\text { input keyboard, } \\
\text { desain baru. }\end{array}$ \\
\hline 2 & $\begin{array}{c}\text { Android versi } \\
4.4 \text { (KitKat) }\end{array}$ & $\begin{array}{l}12 \\
\text { November } \\
2013\end{array}$ & 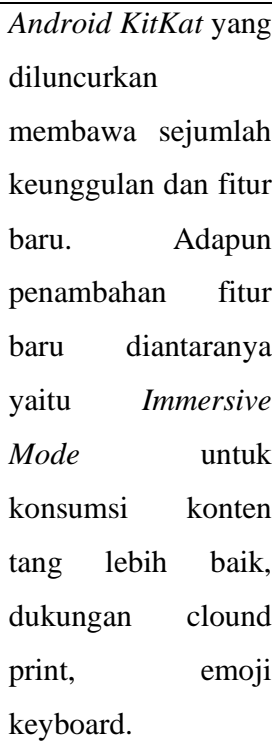 \\
\hline 3 & $\begin{array}{l}\text { Android versi } \\
5.0 \text { (Lolipop) }\end{array}$ & 25 Mei 2014 & $\begin{array}{lr}\text { Android } & \text { Lolipop } \\
\text { yang } & \text { diluncurkan } \\
\text { membawa } & \text { sejumlah }\end{array}$ \\
\hline
\end{tabular}




\begin{tabular}{|c|c|c|c|}
\hline & & & $\begin{array}{l}\text { keunggulan dan fitur } \\
\text { baru. Adapun } \\
\text { penambahan fitur } \\
\text { baru diantaranya } \\
\text { yaitu Smart Lock, } \\
\text { mode tamu, dan } \\
\text { layar kunci baru }\end{array}$ \\
\hline 4 & $\begin{array}{l}\text { Android versi } \\
6.0 \\
\text { (Marshmallow) }\end{array}$ & $\begin{array}{c}17 \text { Agustus } \\
2015\end{array}$ & $\begin{array}{l}\text { Android } \\
\text { Marshmallow yang } \\
\text { diluncurkan } \\
\text { membawa sejumlah } \\
\text { keunggulan dan fitur } \\
\text { baru. Adapun } \\
\text { penambahan fitur } \\
\text { baru diantaranya } \\
\text { yaitu untuk } \\
\text { perizinan } \\
\text { aplikasi, dukungan } \\
\text { resmi sidik jari, dan } \\
\text { Google Now di tap }\end{array}$ \\
\hline 5 & $\begin{array}{l}\text { Android versi } \\
7.0 \text { (Nougat) }\end{array}$ & 1 Juni 2016 & 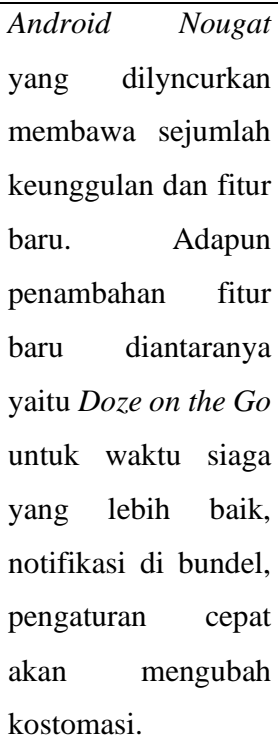 \\
\hline 6 & $\begin{array}{c}\text { Android versi } \\
8.0(\text { Oreo })\end{array}$ & $\begin{array}{c}21 \text { Agustus } \\
2017\end{array}$ & $\begin{array}{l}\text { Android Oreo yang } \\
\text { diluncurkan } \\
\text { membawa sejumlah } \\
\text { keunggulan dan fitur } \\
\text { baru. Adapun } \\
\text { penambahan fitur } \\
\text { baru diantaranya } \\
\text { yaitu koleksi emoji } \\
\text { baru, mengingat kata } \\
\text { sandi dalam aplikasi, }\end{array}$ \\
\hline
\end{tabular}

\begin{tabular}{|l|l|l|}
\hline & $\begin{array}{l}\text { waktu boot lebih } \\
\text { cepat, dan } \\
\text { pengelolaan warna } \\
\text { lebih baik. }\end{array}$ \\
\hline
\end{tabular}

\subsection{Asmaul Husna}

Android adalah sistem operasi berbasis Linux yang digunakan untuk telepon seluler (mobile) seperti smartphone dan computer tabled (PDA). Android juga menyediakan platform terbuka bagi para pengembang untuk menciptakan aplikasi mereka sendiri yang akan digunakan untuk berbagai macam piranti gerak (Murya, 2014).

Menurut bahasa, Asmaul Husna berarti nama-nama yang baik, sedangkan menurut istilah berarti nama-nama baik yang dimiliki Allah sebagai bukti keagungan dan kemuliaan-Nya.

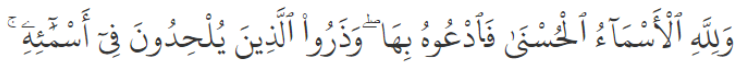

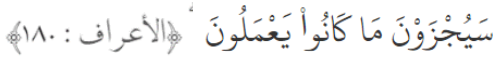

Artinya :

Hanya milik Allah Asmaul Husna, maka bermohonlah kepadaNya dengan menyebut Asmaul Husna itu dan tinggalkanlah orang-orang yang menyimpang dari kebenaran dalam (menyebut) nama-nama-Nya. Nanti mereka akan mendapat balasan terhadap apa yang telah mereka kerjakan (Qs. Al-A'raf/7:180).

Dan Allah mempunyai Asmaul Husna (nama-nama yang terbaik) yang menunjukkan keagungan dan kesempurnaan-Nya. Maka gunakanlah nama-nama itu untuk tawasul kepada Allah dalam meminta sesuatu yang kalian inginkan dan pujilah menggunakan nama-nama terbaik tersebut. Dan tinggalkanlah orang-orang yang menyimpang dari jalan yang benar dalam memperlakukan namanama itu. Yaitu dengan menjadikannya sebagai nama untuk selain Allah, menafikannya dari Allah, menyelewengkan maknanya, atau menyerupakannya dengan selain Allah. Kami akan membalas orang-orang yang menyelewengkan nama-nama itu dari kebenaran dengan azab yang sangat pedih disebabkan apa yang telah mereka perbuat (Qs. Al-A'raf/7:180).

Al-Asma berarti nama dan Al-Husna berarti yang paling baik, sehingga Al-Asma Al-Husna berarti nama-nama yang paling baik dan paling mulia yang hanya ditujukan kepada Tuhan Rabb Al'Alamin saja, dimana dengan nama-nama tersebut Tuhan telah memperkenalkan Zat-nya, Sifat-Nya, dan Perbuatan-Nya kepada setiap makhluk yang diingini-Nya, sehingga seluruh nama yang terbuat dalam Al-Asma Al Husna bukan merupakan pemberian makhluk sebagai bentuk pemujaan kepada Tuhannya, tetapi merupakan penamaan sendiri oleh Tuhan terhadap Diri-Nya dan tidak ada hak dari makhluk untuk menambah atau menguranginya (Puspa, 2014). 


\subsection{Unified Modeling Language (UML)}

Menurut Urva, G. dan Siregar, H.F (2015) hasil pemodelan pada OOAD terdokumentasikan dalam bentuk Unified Modeling Language (UML). UML adalah bahasa spesifikasi standar yang dipergunakan untuk mendokumentasikan, menspesifikasikan dan membangun perangkat lunak. UML merupakan metodologi dalam mengembangkan sistem berorientasi objek dan juga merupakan alat untuk mendukung pengembangan sistem. UML saat ini sangat banyak dipergunakan dalam dunia industri yang merupakan standar bahasa pemodelan umum dalam industri perangkat lunak dan pengembangan sistem.

Alat bantu yang digunakan dalam perancangan berorientasi objek berbasiskan UML adalah sebagai berikut :

1. Use Case Diagram

Use case diagram merupakan pemodelan untuk kelakukan (behavior) sistem informasi yang akan dibuat. Use case mendeskripsikan sebuah interaksi antara satu atau lebih aktor dengan sistem informasi yang akan dibuat. Dapat dikatakan use case digunakan untuk mengetahui fungsi apa saja yang ada di dalam sistem informasi dan siapa saja yang berhak menggunakan fungsi-fungsi tersebut. Simbol- simbol yang digunakan dalam use case diagram, yaitu :

Tabel 2 Simbol Use Case

\begin{tabular}{|l|l|}
\hline Gambar & \multicolumn{1}{|c|}{ Keterangan } \\
\hline Use case menggambarkan \\
fungsionalitas yang \\
disediakan sistem sebagai \\
unit-unit yang bertukar pesan \\
antar unit dengan aktor, \\
biasanya dinyatakan dengan \\
menggunakan kata kerja di \\
awal nama use case. \\
\hline
\end{tabular}

\begin{tabular}{|c|c|}
\hline & $\begin{array}{l}\text { Asosiasi antara aktor dan use } \\
\text { case, digambarkan dengan } \\
\text { garis tanpa panah yang } \\
\text { mengindikasikan siapa atau } \\
\text { apa yang meminta interaksi } \\
\text { secara langsung dan } \\
\text { bukannya mengidikasikan } \\
\text { aliran data. }\end{array}$ \\
\hline & $\begin{array}{l}\text { Asosiasi antara aktor dan use } \\
\text { case yang menggunakan } \\
\text { panah terbuka untuk } \\
\text { mengidinkasikan bila aktor } \\
\text { berinteraksi secara pasif } \\
\text { dengan sistem. }\end{array}$ \\
\hline & $\begin{array}{l}\text { Include, merupakan di dalam } \\
\text { use case lain (required) atau } \\
\text { pemanggilan use case oleh } \\
\text { use case lain, contohnya } \\
\text { adalah pemanggilan sebuah } \\
\text { fungsi program. }\end{array}$ \\
\hline & $\begin{array}{l}\text { Extend, merupakan } \\
\text { perluasan dari use case lain } \\
\text { jika kondisi atau syarat } \\
\text { terpenuhi. }\end{array}$ \\
\hline
\end{tabular}

2. Diagram Aktivitas (Activity Diagram)

Activity Diagram menggambarkan workflow (aliran kerja) atau aktivitas dari sebuah sistem atau proses bisnis. Simbol-simbol yang digunakan dalam activity diagram yaitu :

\section{Tabel 3 Simbol Activity Diagram}

\begin{tabular}{|c|c|}
\hline Gambar & Keterangan \\
\hline & $\begin{array}{l}\text { Start point, diletakkan pada } \\
\text { pojok kiri atas dan } \\
\text { merupakan awal aktifitas. }\end{array}$ \\
\hline & End point, akhir aktifitas. \\
\hline & $\begin{array}{l}\text { Activites, menggambarkan } \\
\text { suatu proses/kegiatan bisnis. }\end{array}$ \\
\hline & $\begin{array}{l}\text { Fork (Percabangan), } \\
\text { digunakan } \\
\text { menunjukkan kegiatan yang } \\
\text { dilakukan secara parallel atau } \\
\text { untuk menggabungkan dua } \\
\text { kegiatan pararel menjadi } \\
\text { satu. }\end{array}$ \\
\hline
\end{tabular}




\begin{tabular}{|l|l|}
\hline & $\begin{array}{l}\text { Join (penggabungan) atau } \\
\text { rake, digunakan untuk } \\
\text { menunjukkan adanya } \\
\text { dekomposisi. }\end{array}$ \\
\hline & $\begin{array}{l}\text { Decision Points, } \\
\text { menggambarkan pilihan } \\
\text { untuk pengambilan } \\
\text { keputusan, true, false. }\end{array}$ \\
\hline & $\begin{array}{l}\text { Swimlane, pembagian } \\
\text { activity diagram untuk } \\
\text { menunjukkan } \\
\text { melakukan apa. }\end{array}$ \\
\hline
\end{tabular}

\section{Flowchart}

Flowchart adalah representasi secara simbolik dari suatu algoritma atau prosedur untuk menyelesaikan suatu masalah, dengan menggunakan flowchart akan memudahkan pengguna melakukan pengecekan bagian-bagian yang terlupakan dalam analisis masalah, disamping itu flowchart juga berguna sebagai fasilitas untuk berkomunikasi antara pemrogram yang bekerja dalam tim suatu proyek. Flowchart membantu memahami urutan-urutan logika yang rumit dan panjang. Flowchart membantu mengkomunikasikan jalannya program ke orang lain akan lebih mudah (Santoso dan Nurmalina, 2017).

Tabel 1 Simbol Flowchart

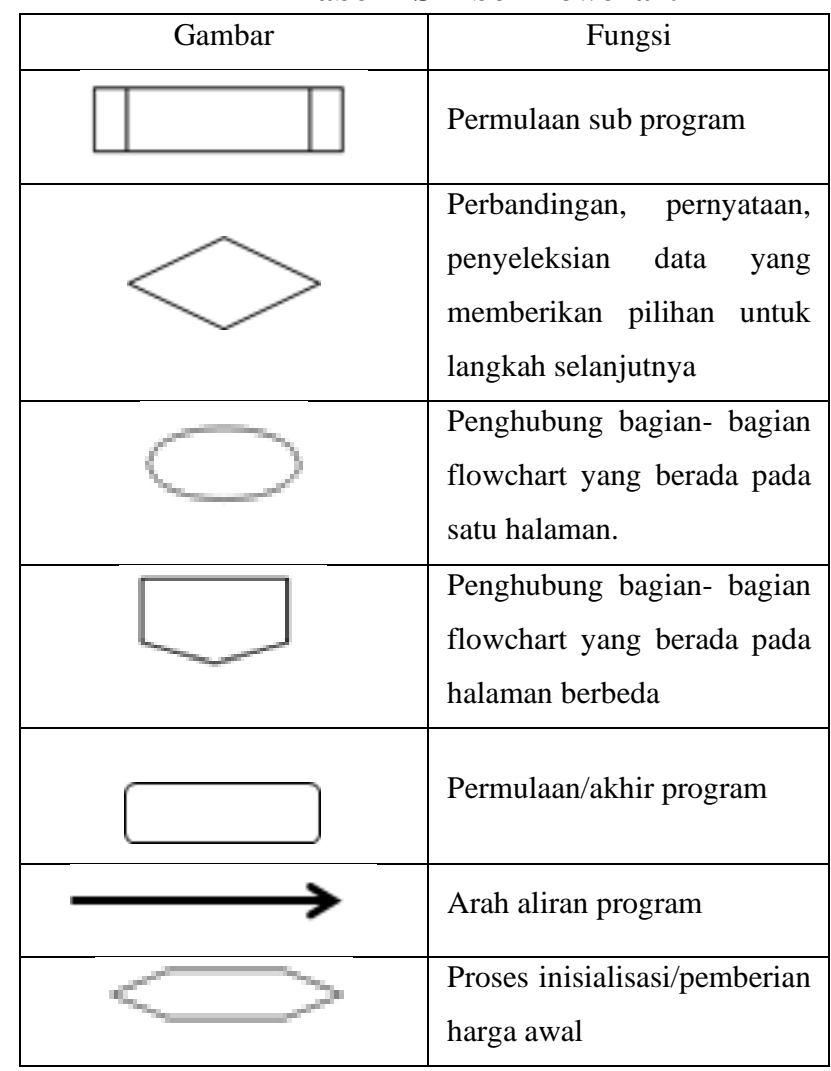

\begin{tabular}{|l|l|}
\hline & $\begin{array}{l}\text { Proses penghitung/ proses } \\
\text { pengolahan data }\end{array}$ \\
\hline & Proses input/output data \\
\hline
\end{tabular}

\section{KONSEP PERANCANGAN}

\subsection{Deskripsi Karya}

Pembuatan game edukasi Asmaul Husna berbasis android ini adalah sebagai salah satu media edukasi pembelajaran Asmaul Husna bagi anak-anak yang hendak mempelajarinya sejak dini.

Tujuan dari game ini adalah untuk melatih daya ingat anak dalam menghafal Asmaul Husna secara urut maupun secara acak. Oleh karena itu, konsep yang dikembangkan dalam pembuatan game ini adalah dengan membuat game jenis puzzle dan quiz berbasis android yang mudah dipahami saat dimainkan oleh murid. Misi game jenis puzzle adalah menyusun potongan-potongan Asmaul Husna menjadi satu urutan yang sesuai, sedangkan misi game jenis quiz ini untuk menebak secara random mulai dari urutan Asmaul Husna, lafadz Asmaul Husna, dan arti Asmaul Husna

Game ini dilengkapi dengan materi 99 Asmaul Husna berupa lafadz, arti, dan audio yang dapat diakses anak sebelum memainkan game. Asmaul Husna yang ditampilkan dalam game ini bersumber dari materi yang digunakan di TPA Cabe Rawit Masjid Darussalam.

Game jenis puzzle ini terdiri dari 11 level. Masing-masing level menampilkan 9 Asmaul Husna secara acak yang perlu disusun oleh siswa secara berurutan. Sedangkan game jenis quiz ini terdiri atas game tebak Asmaul Husna dan game tebak arti. Dimana murid perlu mimilih jabawan yang tepat pada soal yang disajikan secara random sesuai game yang dipilih, baik tebak Asmaul Husna ataupun tebak arti.

\subsection{Proses}

Pembuatan game ini tentunya melalui beberapa rangkaian tahapan, terdapat 3 tahapan proses kerja yang dilalui, yaitu proses pra produksi, produksi, dan pasca produksi. Berikut adalah gambar diagram proses kerja pembuatan "Game Edukasi Asmaul Husna Berbasis Android". 


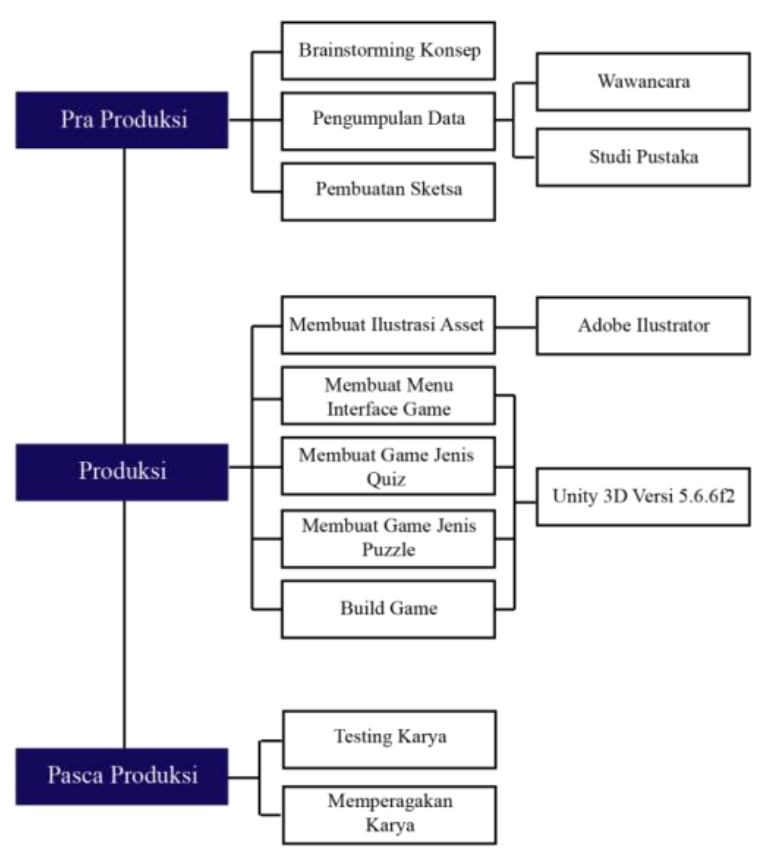

Gambar 1 Alur Proses

\subsection{Perancangan Game}

\section{a. Skenario}

Skenario yang akan dibuat dalam game ini adalah membuat user mempelajari materi yang disajikan dalam aplikasi terlebih dahulu. Kemudian sebagai media evaluasi hasil belajar user, user diminta untuk memainkan game puzzle dan game quiz. Dimana game puzzle untuk mengukur kemampuan user dalam menghafal materi secara berurutan, sedangkan game quiz untuk mengukur kemampuan user dalam menghafal materi secara acak.

\section{b. Levelling}

Levelling yang akan dibuat digunakan untuk jenis game puzzle. Jenis game puzzle yang disajikan adalah game drag\&drop. Dimana level terdiri atas 11 level, tiap level menyajikan 9 urutan Asmaul Husna. Level ditentukan dari semakin banyak Asmaul Husna yang mampu dihafal oleh user. Sehingga semakin tinggi level, semakin banyak Asmaul Husna yang perlu disusun dan dilengkapi oleh user dalam game. Serta semakin sedikit waktu yang disajikan untuk menyelesaikan level.

\section{c. Timer}

Timer pada game quiz disajikan setiap 1 soal quiz, setiap waktu berakhir soal akan berganti hingga soal yang disajikan habis. Sedangkan timer pada game puzzle disajikan untuk mengetahui berapa lama user dapat menyelesaikan tantangan yang ditampilkan pada tiap level, dan user akan megulangi level yang dimainkan jika batas waktu yang ditentukan telah berakhir.

\section{d. Random}

Random pada game quiz dilakukan pada setiap soal yang ditampilkan, soal akan berganti setiap 15 detik dan dimunculkan secara random setiap kali dimainkan. Sedangkan random pada game puzzle dilakukan pada soal dan jawaban puzzle yang disajikan.

\section{e. Scorring}

Scorring pada game quiz adalah menghitung skor ketika user menjawab dengan benar setiap soal yang ditampilkan. Setiap soal benar akan dihitung 1 poin. Sedangkan scorring pada game puzzle adalah menghitung skor saat user menyusun dengan benar puzzle yang kosong, jawaban benar akan bertambah 10 poin sedangkan jawaban salah akan berkurang 5 poin.

\subsection{Perancangan Sistem}

\section{a. Use Case Diagram}

Use case adalah rangkaian/uraian pengguna yang saling terkait dan membentuk sistem secara teratur yang diawasi oleh sebuah aktor. Use case digunakan untuk membentuk apa yang dilakukan oleh pengguna yang direalisasikan oleh sebuah sistem.

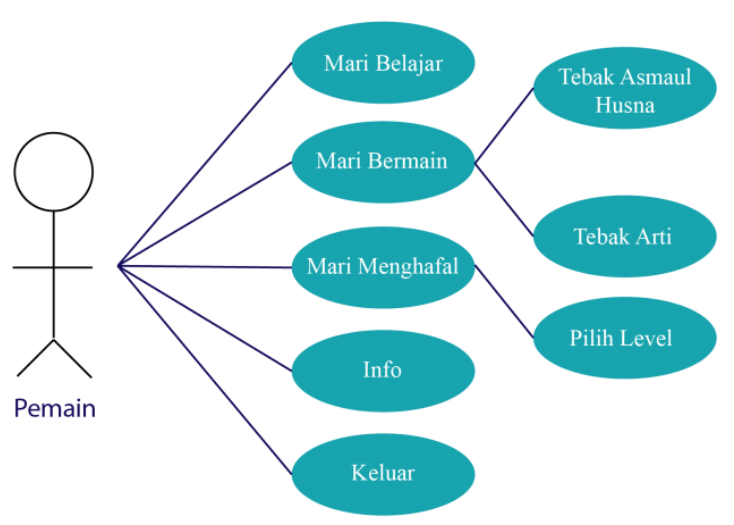

Gambar 2 Use Case Diagram

\section{b. Activity Diagram}

Diagram activity adalah bentuk visual dari aliran kerja dari kedua belah pihak baik user maupun sistem yang berisi aktivitas dalam sebuah sistem, Dalam aplikasi ini terbagi dalam aktivitas yang dilakukan user dan sitem yang berjalan sesuai dengan perintah.

Berikut ini adalah diagram aktivitas menggambarkan alur kontrol secara garis besar :

\section{i. Activity Diagram Main Menu}

Activity diagram main menu ini menggambarkan kejadian dimana user dapat menjalankan aplikasi, mulai dari membuka aplikasi, menampilkan menu utama kemudian keluar dari aplikasi. 


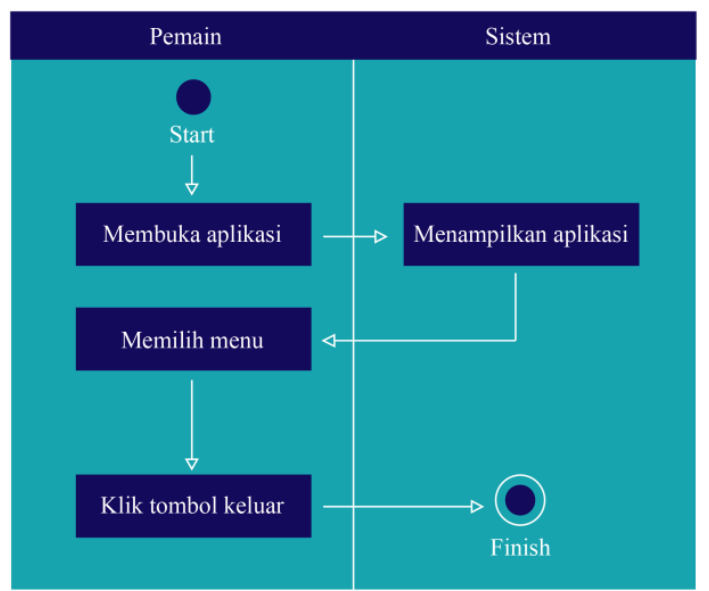

Gambar 3 Activity diagram main menu

\section{ii. Activity Diagram Mari Belajar}

Activity diagram mari belajar ini menggambarkan kejadian dimana user ketika memilih tombol mari belajar, lalu sistem akan menampilkan pilihan menu mari belajar dan user bisa langsung memilih materi yang mana untuk dipelajari. Lalu aplikasi akan menampilkan materi Asmaul Husna yang dipilih user.

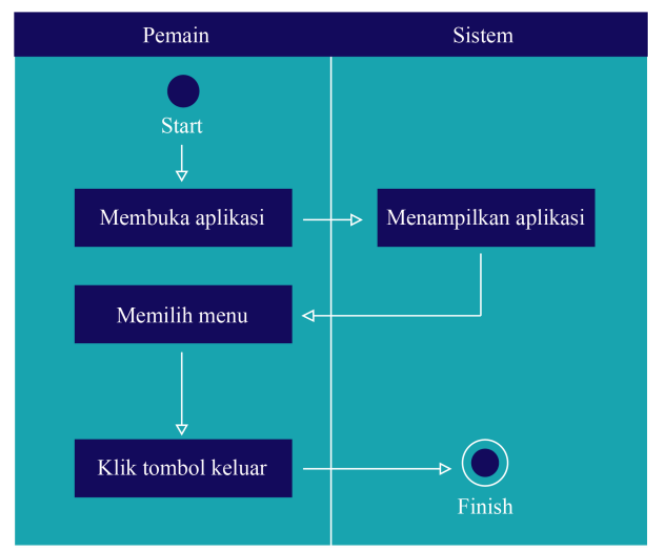

Gambar 4 Activity diagram mari belajar

iii. Activity Diagram Tentang Aplikasi

Activity diagram tentang aplikasi ini menggambarkan kejadian dimana user ketika memilih tombol tentang aplikasi, lalu sistem akan menampilkan user interface dari tentang aplikasi berisi tentang informasi pembuat dari aplikasi.

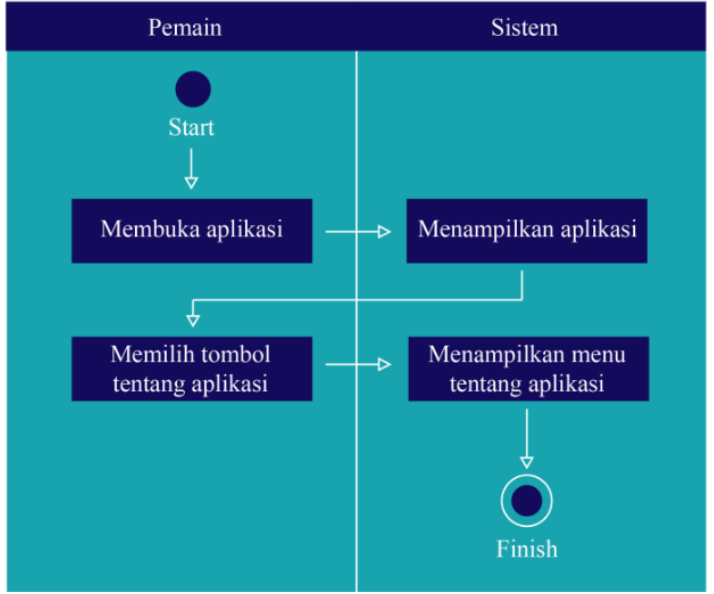

\section{Gambar 5 Activity diagram Tentang Aplikasi}

\section{iv. Activity Diagram Mari Bermain}

Activity diagram mari bermain ini menggambarkan kejadian dimana user ketika memilih tombol mari bermain, sistem akan menampilkan pilihan game, kemudian user mimilih game yang akan dimainkan. Setelah menyelesaikan game, user akan mendapat skor.

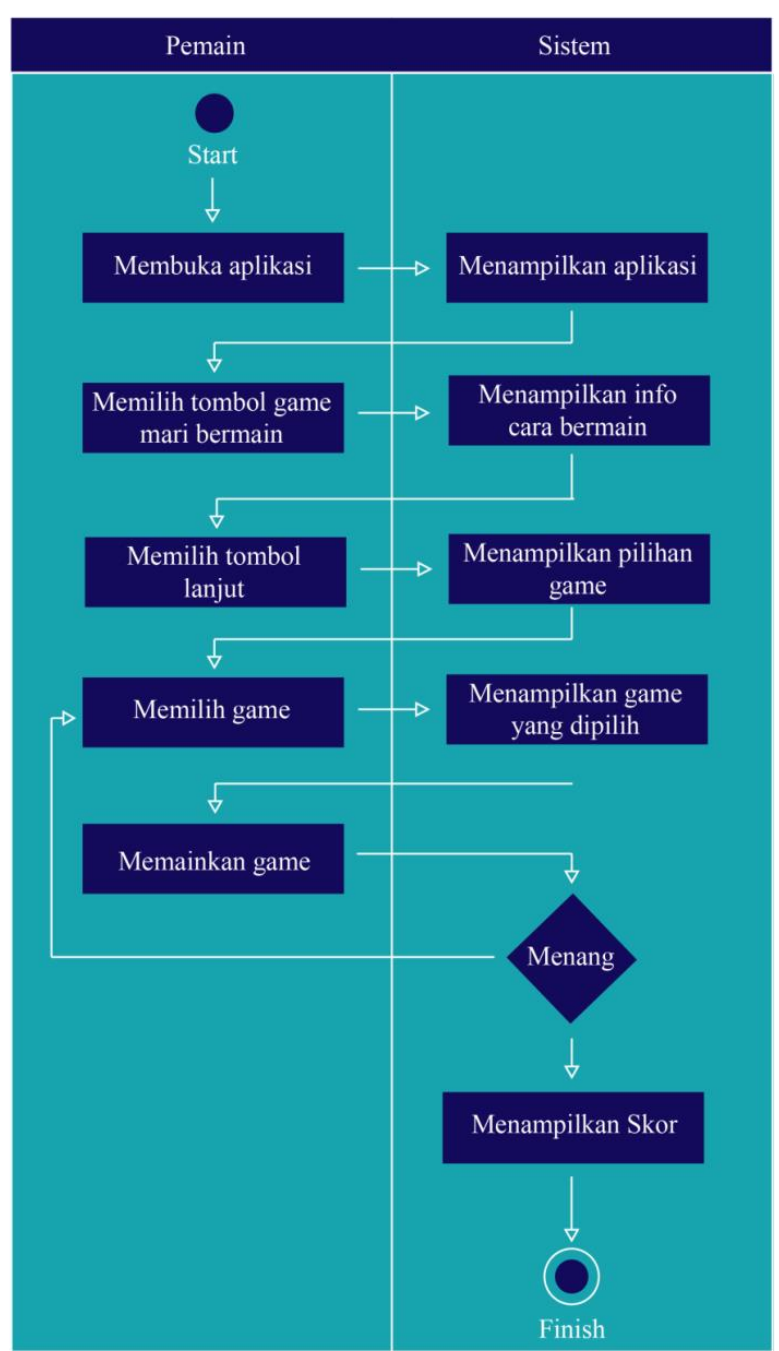

Gambar 6 Activity diagram mari bermain 
v. Activity Diagram Mari Menghafal

Activity diagram mari menghafal ini menggambarkan kejadian dimana user ketika memilih tombol mari menghafal, sistem akan menampilkan pilihan level, kemudian user akan mimilih level game yang akan dimainkan.

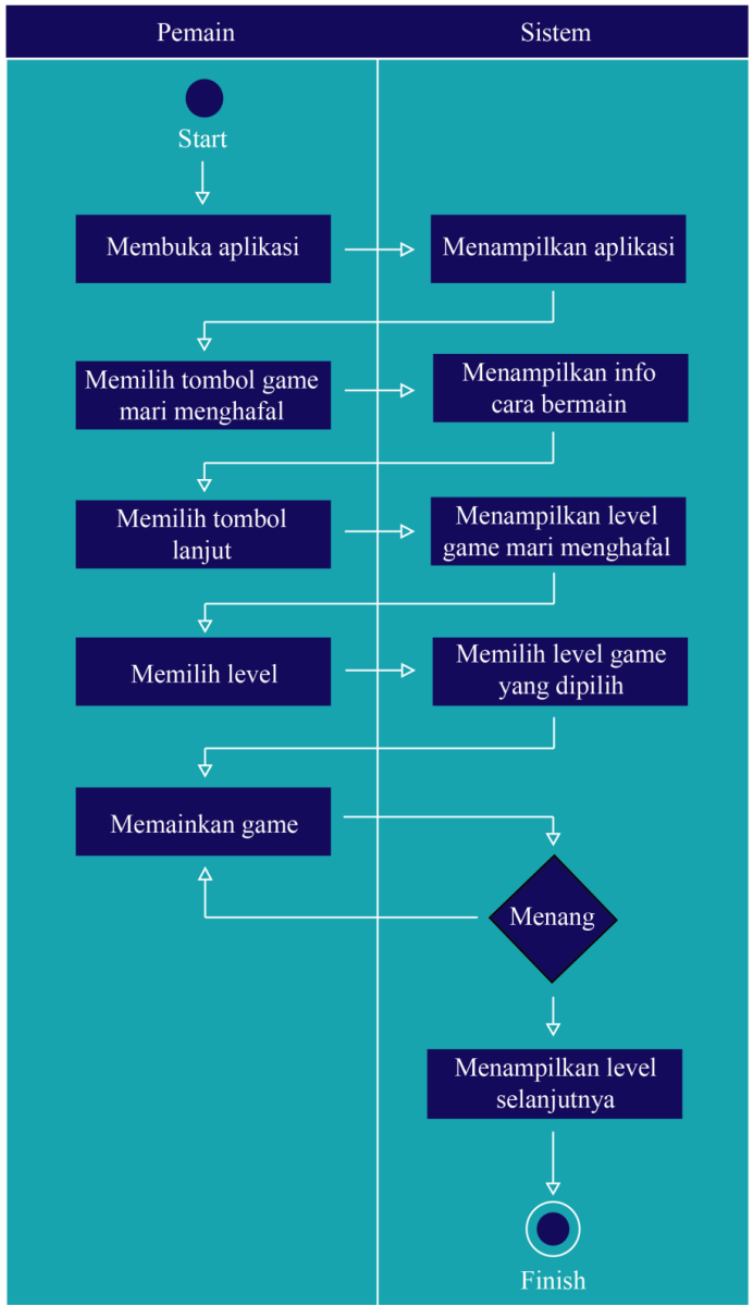

Gambar 7 Activity diagram mari menghafal

\subsection{Perancangan User Interface}

Sebelum mulai membuat desain yang dibutuhkan dalam pembuatan User Interface aplikasi dengan software adobe illustrator. Pertama-tama membuat struktur menu dan desain layout untuk membantu pengerjaan dan layout suatu desain, selain mempermudah pengerjaan, dapat menjadi panduan untuk mengetahui desain apa saja yang dibutuhkan untuk membuat aplikasi. Sehingga hasil akhir tidak terlalu menyimpang dari konsep awal.

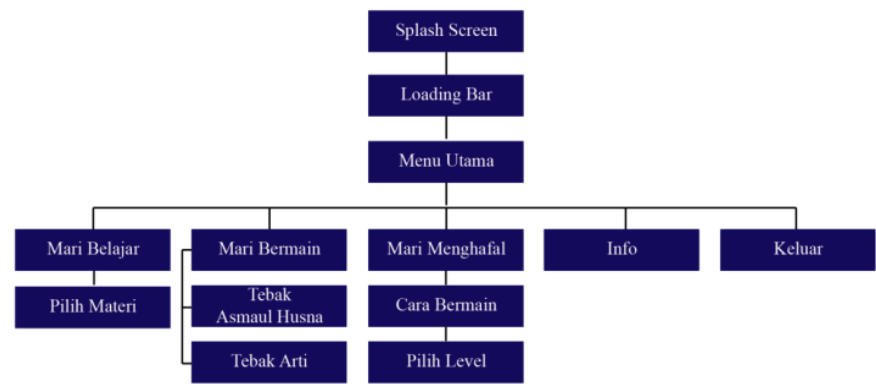

Gambar 8 Stuktur Menu Aplikasi

\subsection{Perancangan Uji Coba Sistem}

Berikut adalah spesifikasi sistem yang nantinya akan digunakan untuk uji coba aplikasi game.

\section{Tabel 5 Spesifikasi Uji Coba Smartphone Android}

\begin{tabular}{|c|c|c|c|c|c|}
\hline \multirow{2}{*}{$\begin{array}{c}\text { Perangkat } \\
\text { Smartphone } \\
\text { Android }\end{array}$} & \multicolumn{5}{|c|}{ Spesifikasi } \\
\hline & Processor & RAM & $\begin{array}{l}\text { Resolusi } \\
\text { Kamera }\end{array}$ & $\begin{array}{c}\text { Resolusi } \\
\text { Layar }\end{array}$ & $\begin{array}{c}\text { OS } \\
\text { Android }\end{array}$ \\
\hline Perangkat 1 & $\begin{array}{l}\text { Quad } \\
\text { Core }\end{array}$ & $1 \mathrm{~GB}$ & $5 \mathrm{MP}$ & $\begin{array}{c}540 \mathrm{x} \\
960 \text { pixel } \\
\mathrm{s}\end{array}$ & $\begin{array}{c}\text { Android } \\
5.1 .1 \\
\text { (Lollipo } \\
\text { p) }\end{array}$ \\
\hline Perangkat 2 & $\begin{array}{c}\text { A53Exyn } \\
\text { os 7885, } \\
\text { Octa-core } \\
(2 \times 2,2 \\
\text { GHz } \\
\text { Cortex- } \\
\text { A73 \& } \\
6 x 1,6 \\
\text { GHz } \\
\text { Cortex- } \\
\text { A53) }\end{array}$ & $6 \mathrm{~GB}$ & $16 \mathrm{MP}$ & $\begin{array}{l}720 \mathrm{x} \\
1280 \\
\text { pixels }\end{array}$ & $\begin{array}{c}\text { Android } \\
8.0 \\
\text { (Oreo) }\end{array}$ \\
\hline Perangkat 3 & $\begin{array}{c}\text { Qualcom } \\
\text { m } \\
\text { MSM891 } \\
7 \\
\text { Snapdrag } \\
\text { on } \\
425 \text { Quad } \\
- \\
\text { core 1,4G } \\
\text { Hz } \\
\text { Cortex- }\end{array}$ & $2 \mathrm{~GB}$ & $14 \mathrm{MP}$ & $\begin{array}{l}1080 \\
\text { x2220 } \\
\text { pixels }\end{array}$ & $\begin{array}{c}\text { Android } \\
7.0 \\
\text { (Nougat } \\
\text { ) }\end{array}$ \\
\hline Perangkat 4 & $\begin{array}{c}\text { Octa-core } \\
\text { Max } 1.40 \\
\mathrm{GHz}\end{array}$ & $3 \mathrm{~GB}$ & $13 \mathrm{MP}$ & $\begin{array}{c}720 \mathrm{x} \\
1280 \\
\text { pixels }\end{array}$ & $\begin{array}{c}\text { Android } \\
7.0 \\
\text { (Nougat } \\
\text { ) }\end{array}$ \\
\hline
\end{tabular}




\section{HASIL DAN PEMBAHASAN}

\subsection{Implementasi Sistem}

\section{a. Tampilan Halaman Splash Screen}

Splash screen adalah tampilan awal dari game edukasi Bismillah Asmaul Husna.

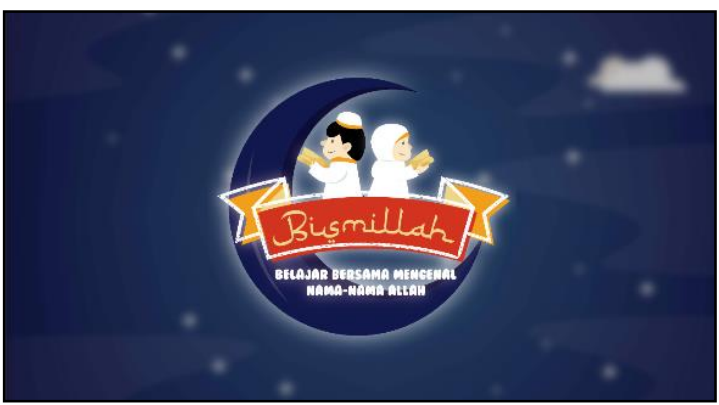

Gambar 9 Tampilan Halaman Splash Screen

\section{b. Tampilan Halaman Loading}

Loading adalah tampilan proses game menuju menu utama pada game.

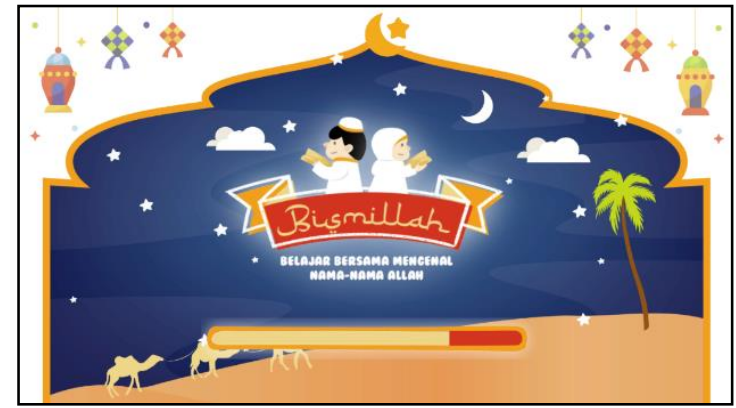

Gambar 10 Tampilan Halaman Loading

\section{c. Tampilan Halaman Menu Utama}

Halaman menu utama adalah tampilan yang berisi lima pilihan menu untuk memasuki halaman lainnya.

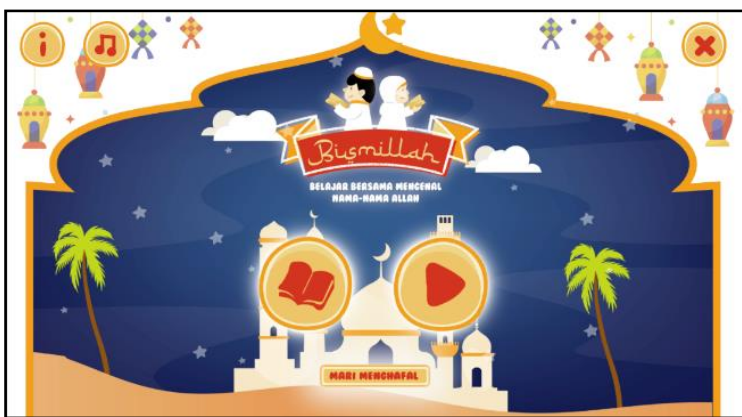

Gambar 11 Tampilan Halaman Menu Utama

\section{d. Tampilan Halaman Mari Belajar}

Tampilan dari materi Asmaul Husna yang disediakan untuk bahan belajar yang akan digunakan user dalam memainkan game.
1. Tampilan Halaman Menu Mari Belajar

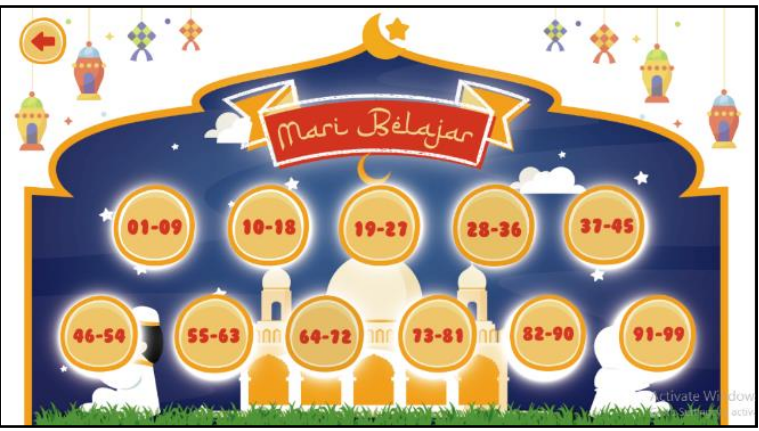

Gambar 12 Tampilan Halaman Menu Mari Belajar

2. Tampilan Halaman Mari Belajar Metode 1

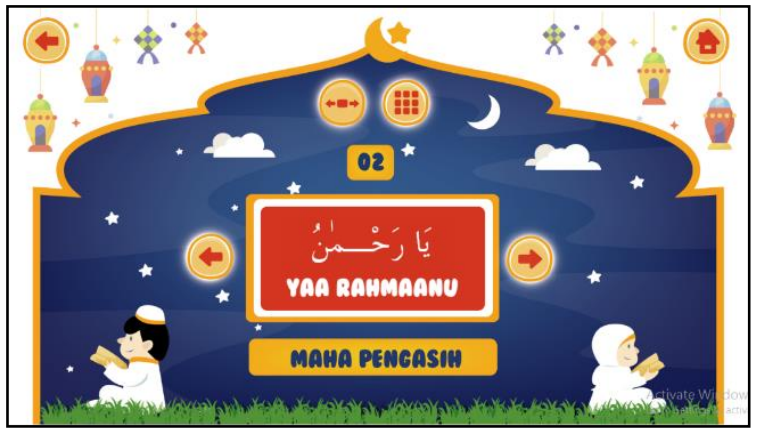

Gambar 13 Tampilan Halaman Mari Belajar Metode 1

3. Tampilan Halaman Mari Belajar Metode 2

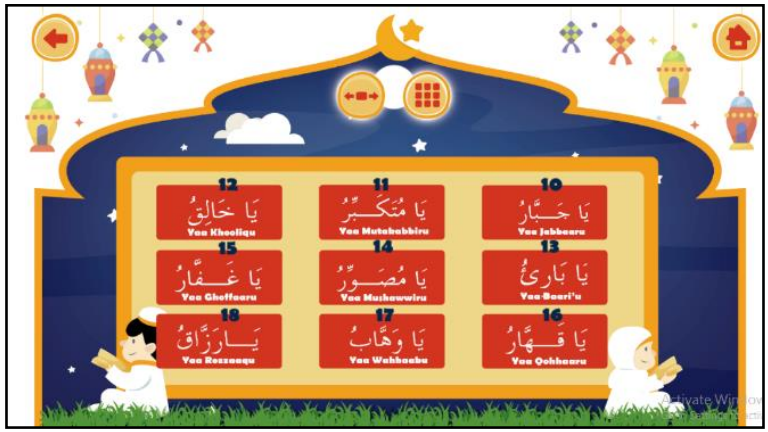

Gambar 14 Tampilan Halaman Mari Belajar Metode 2

\section{e. Tampilan Halaman Mari Bermain}

Halaman mari bermain adalah tampilan yang berisi game quiz.

1. Tampilan Halaman Cara Bermain Mari Bermain

Agar user mengetahui bagaimana cara memainkan game ini, user akan ditampilkan halaman cara bermain terlebih dahulu. 


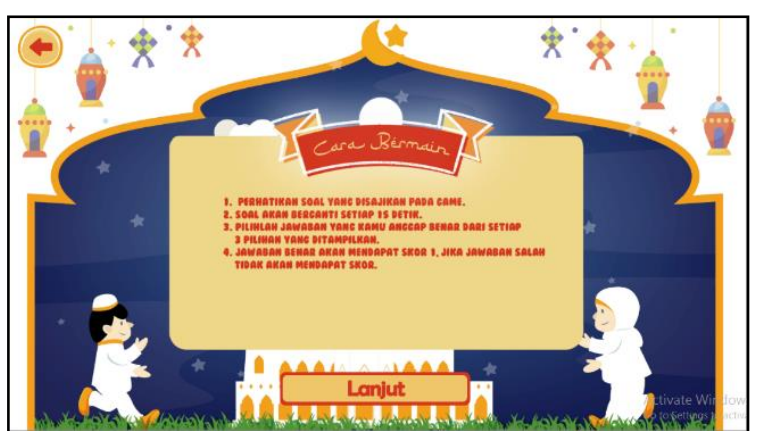

Gambar 15 Tampilan Halaman Cara Bermain Mari Bermain

2. Tampilan Halaman Menu Mari Bermain

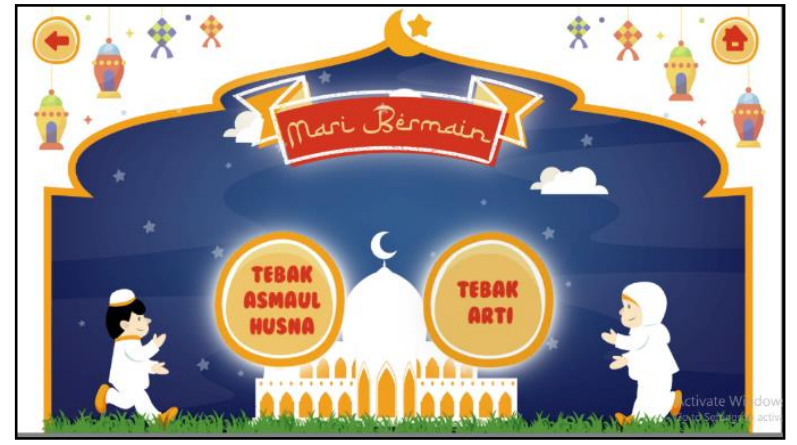

Gambar 16 Tampilan Halaman Menu Mari Bermain

3. Tampilan Halaman Tebak Asmaul Husna

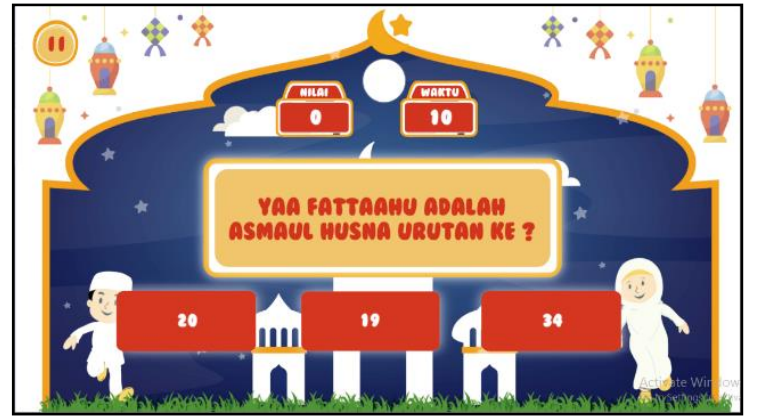

Gambar 17 Tampilan Halaman Tebak Asmaul Husna

4. Tampilan Halaman Tebak Arti

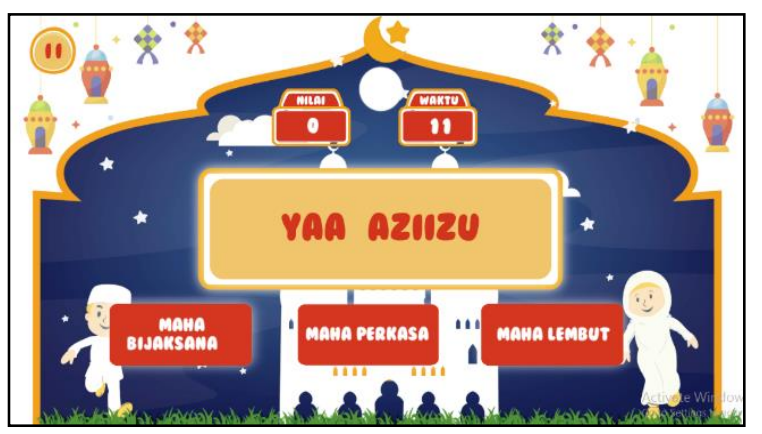

Gambar 18 Tampilan Halaman Tebak Arti

f. Tampilan Halaman Mari Menghafal

1. Tampilan Halaman Menu Mari Menghafal

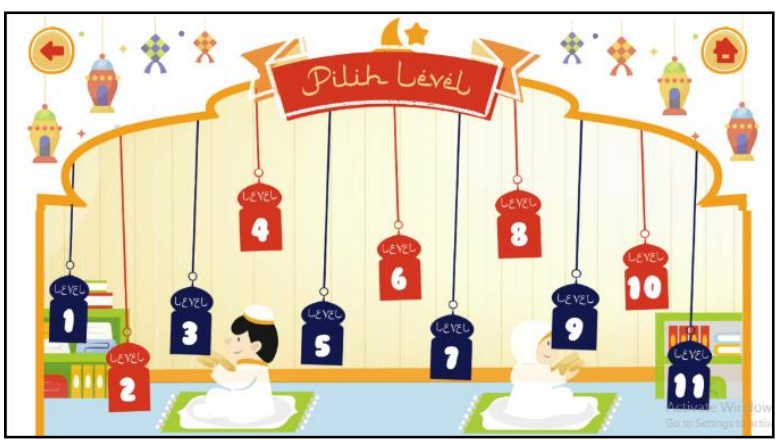

Gambar 19 Tampilan Halaman Menu Mari Menghafal

2. Tampilan Halaman Game Mari Menghafal

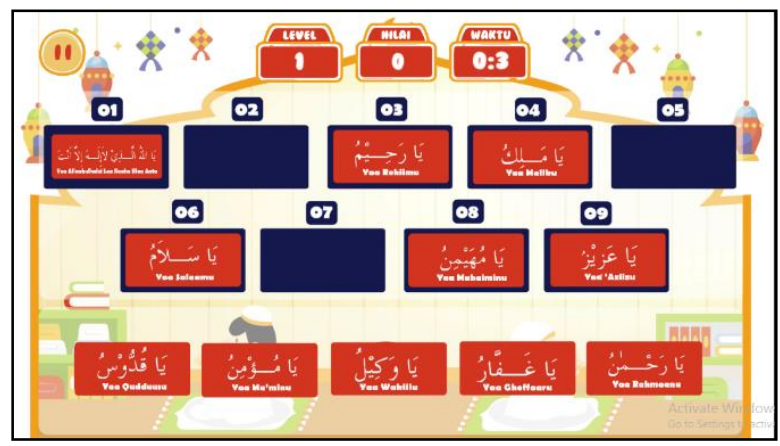

Gambar 20 Tampilan Halaman Game Mari Menghafal

\subsection{Gambar Kebutuhan Pemakaian Sistem}

Kebutuhan pemakaian sistem yang dibutuhkan dalam pembuatan game edukasi Asmaul Husna Bismillah adalah sebagai berikut :

1. Objek Game
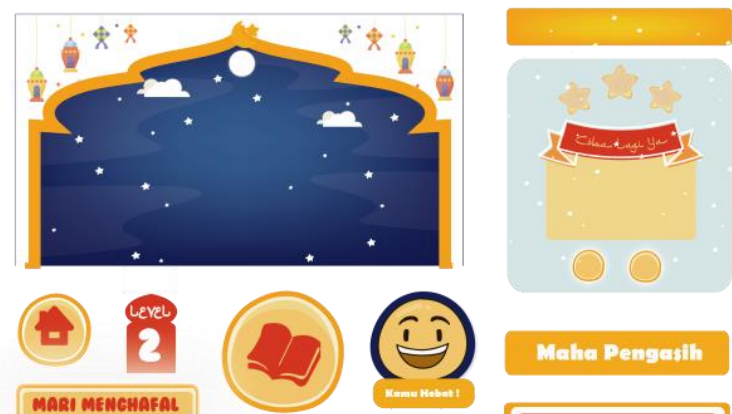

MARI MEMEMAFat
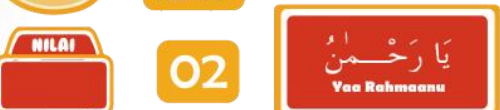


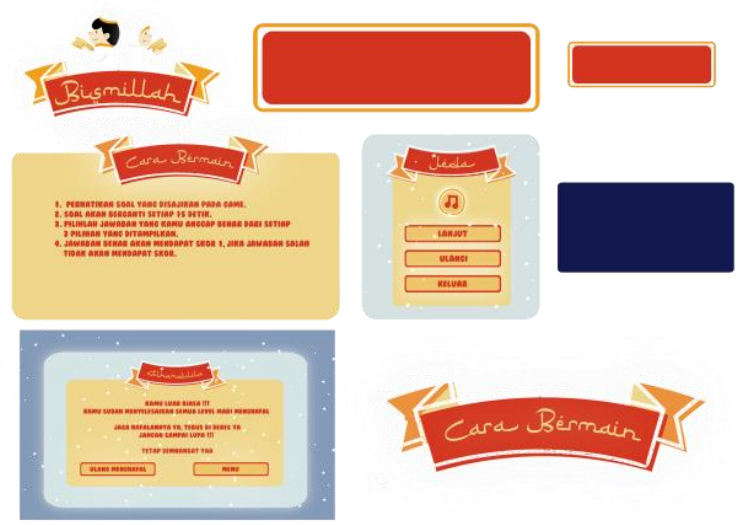

Gambar 21 Objek Game

Tabel 6 Ukuran Objek Game

\begin{tabular}{|c|c|}
\hline Aset & Ukuran \\
\hline Background & $1280 \times 720 \mathrm{px}$ \\
\hline Button (lingkaran kecil) & $78 \times 78 \mathrm{px}$ \\
\hline Button (lingkaran besar) & $163 \times 163 \mathrm{px}$ \\
\hline Button (persegi panjang) & 286 x $51 \mathrm{px}$ \\
\hline Button (tak beraturan) & $68 \times 103$ px \\
\hline Papan skor dan waktu & 128 x 96 px \\
\hline Ikon Benar dan Salah & 267 x 300 px \\
\hline Puzzle & 133 x 62 px \\
\hline Papan Game Puzzle & 206 x 105 px \\
\hline Papan Belajar Asmaul Husna & 434 x $220 \mathrm{px}$ \\
\hline $\begin{array}{c}\text { Papan Belajar Arti Asmaul } \\
\text { Husna }\end{array}$ & 425 x 64 px \\
\hline $\begin{array}{l}\text { Papan Belajar Urutan } \\
\text { Asmaul Husna }\end{array}$ & $80 \times 61$ px \\
\hline $\begin{array}{c}\text { Pop Up Game Berhasil \& } \\
\text { Gagal }\end{array}$ & 476 x 602 px \\
\hline Pop Up Cara Bermain & 759 x $485 \mathrm{px}$ \\
\hline Pop Up Game Selesai & 1074 x 643 px \\
\hline Papan Soal Game Quiz & 288 x $81 \mathrm{px}$ \\
\hline Papan Jawaban Game Quiz & 114 x 46 px \\
\hline Logo Game & 471 x $297 \mathrm{px}$ \\
\hline Judul Game & $471 \times 138 \mathrm{px}$ \\
\hline
\end{tabular}

\subsection{Flowchart Game}

Flowchart merupakan urutan-urutan langkah kerja suatu proses yang digambarkan dengan menggunakan simbol-simbol yang tersusun secara sistematis.
1. Flowchart Game Quiz

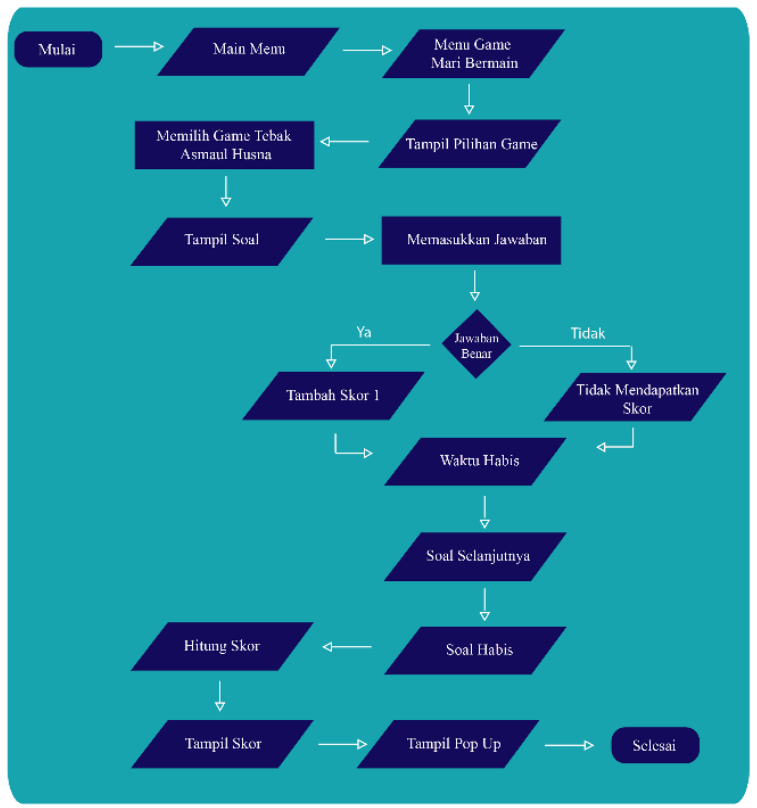

Gambar 22 Flowchart Game Quiz

2. Flowchart Game Puzzle

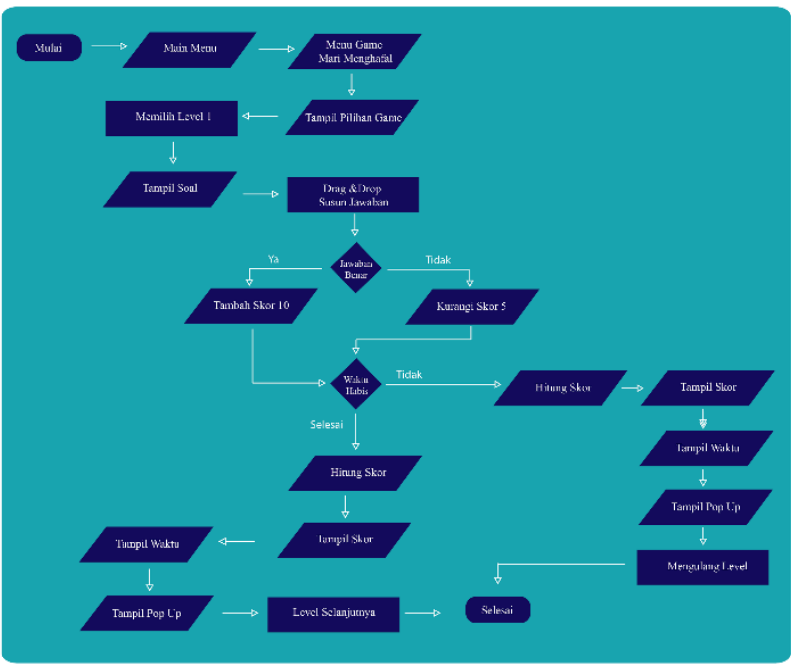

Gambar 23 Flowchart Game Puzzle

\subsection{Pengujian Sistem}

a. Uji coba pada perangkat

Tahap ini merupakan tahap uji coba memasang dan menjalankan aplikasi yang sudah dibangun kedalam smartphone Android. Uji coba aplikasi interaktif ini telah dilakukan di empat perangkat smartphone Android dengan versi sistem operasi yang berbeda. Apabila ada masalah pada aplikasi tersebut akan dilakukan perbaikan (trial and error) hingga aplikasi dapat dijalankan dan berfungsi 
sebagai mestinya. Berikut adalah spesifikasi perangkat yang penulis gunakan untuk uji coba aplikasi :

\section{Tabel 7 Hasil Uji Coba Pada Smartphone Android}

\begin{tabular}{|c|c|c|c|c|}
\hline Proses & \multicolumn{4}{|c|}{ Perangkat Uji Coba } \\
\hline Operasi & Perangkat & Perangkat & Perangkat & Perangkat \\
\hline Aplikasi & 1 & 2 & 3 & 4 \\
\hline $\begin{array}{c}\text { Loading Awal } \\
\text { Game }\end{array}$ & $5.32 \mathrm{~s}$ & $5.32 \mathrm{~s}$ & $4.87 \mathrm{~s}$ & $4.59 \mathrm{~s}$ \\
\hline $\begin{array}{l}\text { Menampilkan } \\
\text { Menu Utama }\end{array}$ & $1 \mathrm{~s}$ & $1 \mathrm{~s}$ & $1 \mathrm{~s}$ & $1 \mathrm{~s}$ \\
\hline $\begin{array}{c}\text { Menampilkan } \\
\text { Halaman } \\
\text { Menu Mari } \\
\text { Belajar }\end{array}$ & $1 \mathrm{~s}$ & $1 \mathrm{~s}$ & $1 \mathrm{~s}$ & $1 \mathrm{~s}$ \\
\hline $\begin{array}{l}\text { Menampilkan } \\
\text { Halaman } \\
\text { Mari Belajar } \\
1\end{array}$ & $1 \mathrm{~s}$ & $1 \mathrm{~s}$ & $1 \mathrm{~s}$ & $1 \mathrm{~s}$ \\
\hline $\begin{array}{l}\text { Menampilkan } \\
\text { Halaman } \\
\text { Mari Belajar } \\
2\end{array}$ & $1 \mathrm{~s}$ & $1 \mathrm{~s}$ & $2 \mathrm{~s}$ & $1 \mathrm{~s}$ \\
\hline $\begin{array}{c}\text { Menampilkan } \\
\text { Halaman } \\
\text { Menu Mari } \\
\text { Bermain }\end{array}$ & $1 \mathrm{~s}$ & $1 \mathrm{~s}$ & $1 \mathrm{~s}$ & $1 \mathrm{~s}$ \\
\hline $\begin{array}{c}\text { Menampilkan } \\
\text { Halaman } \\
\text { Game Mari } \\
\text { Bermain }\end{array}$ & $1 \mathrm{~s}$ & $1 \mathrm{~s}$ & $2 \mathrm{~s}$ & $1 \mathrm{~s}$ \\
\hline $\begin{array}{c}\text { Respon klik } \\
\text { Game Mari } \\
\text { Bermain }\end{array}$ & Baik & Baik & Baik & Baik \\
\hline $\begin{array}{c}\text { Menampilkan } \\
\text { Halaman } \\
\text { Menu Mari } \\
\text { Menghafal }\end{array}$ & $1 \mathrm{~s}$ & $1 \mathrm{~s}$ & $1 \mathrm{~s}$ & $1 \mathrm{~s}$ \\
\hline $\begin{array}{c}\text { Menampilkan } \\
\text { Halaman } \\
\text { Game Mari } \\
\text { Menghafal }\end{array}$ & $1 \mathrm{~s}$ & $1 \mathrm{~s}$ & $1 \mathrm{~s}$ & $1 \mathrm{~s}$ \\
\hline $\begin{array}{c}\text { Respon Drag } \\
\text { \& Drop Game } \\
\text { Mari } \\
\text { Menghafal }\end{array}$ & Baik & Baik & Baik & Baik \\
\hline $\begin{array}{c}\text { Menampilkan } \\
\text { Halaman Cara } \\
\text { Bermain }\end{array}$ & $1 \mathrm{~s}$ & $1 \mathrm{~s}$ & $1 \mathrm{~s}$ & $1 \mathrm{~s}$ \\
\hline $\begin{array}{c}\text { Menampilkan } \\
\text { Halaman }\end{array}$ & $1 \mathrm{~s}$ & $1 \mathrm{~s}$ & $1 \mathrm{~s}$ & $1 \mathrm{~s}$ \\
\hline
\end{tabular}

\begin{tabular}{|c|l|l|l|l|}
\hline $\begin{array}{c}\text { Tentang } \\
\text { Aplikasi }\end{array}$ & & & & \\
\hline
\end{tabular}

Berdasarkan hasil pengujian aplikasi yang dilakukan pada tiga perangkat maka dapat disimpulkan bahwa aplikasi dapat diberjalan pada semua perangkat, mulai dari OS Android versi Lollipop hingga versi Oreo.

\section{b. Analisis Kuisioner Penilaian Siswa Terhadap Game}

Setelah menggunakan game Bismillah, siswa diberikan kuisioner untuk menilai game Bismillah dengan aspek penilaian meliputi tombol navigasi di dalam game, tampilan game, kemudahan penggunaan game, interaktifitas game dan penilaian keseluruhan game. Dari kuisioner yang diberikan, didapatkan data yang disajikan pada tabel berikut :

Tabel 5 Rekapitulasi Kuisioner validasi Pengguna

\begin{tabular}{|c|c|c|c|}
\hline Aspek Penilaian & Nilai & $\begin{array}{c}\text { Nilai } \\
\text { Maksimal }\end{array}$ & $\begin{array}{l}\text { Persentase } \\
\text { (Dalam \%) }\end{array}$ \\
\hline \multicolumn{4}{|c|}{ Tombol navigasi di dalam game } \\
\hline $\begin{array}{l}\text { Apakah tombol } \\
\text { navigasi } \quad \text { game } \\
\text { mudah dipahami? }\end{array}$ & 72 & 85 & $85 \%$ \\
\hline $\begin{array}{lr}\text { Apakah tombol } \\
\text { navigasi game } \\
\text { mudah diguanakan? }\end{array}$ & 75 & 85 & $88 \%$ \\
\hline \multicolumn{4}{|l|}{ Tampilan Game } \\
\hline $\begin{array}{l}\text { Apakah tampilan } \\
\text { game mudah } \\
\text { dipahami ? }\end{array}$ & 71 & 85 & $83 \%$ \\
\hline $\begin{array}{l}\text { Apakah tampilan } \\
\text { game menarik? }\end{array}$ & 80 & 85 & $94 \%$ \\
\hline \multicolumn{4}{|c|}{ Kemudahan Penggunaan Game } \\
\hline $\begin{array}{l}\text { Apakah game ini } \\
\text { mudah } \\
\text { digunakan? }\end{array}$ & 79 & 85 & $93 \%$ \\
\hline $\begin{array}{l}\text { Apakah game ini } \\
\text { nyaman } \\
\text { digunakan? }\end{array}$ & 78 & 85 & $92 \%$ \\
\hline \multicolumn{4}{|l|}{ Interaktifitas Game } \\
\hline $\begin{array}{l}\text { Apakah } \\
\text { interaktifitas game } \\
\text { mudah dipahami? }\end{array}$ & 69 & 85 & $81 \%$ \\
\hline $\begin{array}{l}\text { Apakah game ini } \\
\text { interaktif dapat } \\
\text { membantu }\end{array}$ & 79 & 85 & $93 \%$ \\
\hline
\end{tabular}




\begin{tabular}{|c|c|c|c|}
\hline $\begin{array}{l}\text { memahami dan } \\
\text { menghafal Asmaul } \\
\text { Husna? }\end{array}$ & & & \\
\hline \multicolumn{4}{|l|}{ Penilaian Game } \\
\hline $\begin{array}{l}\text { Bagaimana } \\
\text { penilaian anda } \\
\text { terhadap aplikasi } \\
\text { game yang telah } \\
\text { saya buat? }\end{array}$ & 77 & 85 & $90 \%$ \\
\hline $\begin{array}{l}\text { Apakah aplikasi } \\
\text { game yang telah } \\
\text { saya buat sangat } \\
\text { membantu anak } \\
\text { dalam mempelajari } \\
\text { dan menghafal } \\
\text { Asmaul Husna? }\end{array}$ & 80 & 85 & $94 \%$ \\
\hline TOTAL & 760 & 850 & $89 \%$ \\
\hline
\end{tabular}

Nilai maksimal adalah 17 x 10 × $5=850$. Dengan 17 merupakan responden yang mengisi kuisioner, 10 merupakan jumlah pernyataan dan 5 merupakan skor tertinggi tiap pertanyaan. Jika dibandingkan antara hasil kuisioner penilaian siswa terhadap game ini dengan nilai maksimal, maka didapatkan $760: 850=$ 0,89 atau didapatkan persentase sebesar $89 \%$. Berdasarkan hal tersebut, bisa disimpulkan bahwa hampir seluruh siswa memberikan penilaian yang bisa dikategorikan Sangat Baik pada game Bismillah yang telah mereka gunakan.

\section{KESIMPULAN DAN SARAN}

\subsection{Kesimpulan}

Kesimpulan pada pembuatan tugas akhir yang berjudul Pembuatan Aplikasi Game Edukasi Asmaul Husna berbasis Android, adalah sebagai berikut:

1. Telah berhasil dibuat Aplikasi Game Edukasi Asmaul Husna berbasis Android.

2. Berdasarkan hasil kuisioner yang telah saya bagikan kepada siswa TPA Cabe Rawit Masjid Darussalam, game edukasi Asmaul Husna berbasis Android ini memiliki tampilan menarik serta interaktifitas yang baik sehingga mampu membantu anak dalam mempelajari dan menghafal Asmaul Husna. Selain itu, game edukasi Asmaul Husna berbasis Android ini mudah serta nyaman digunakan untuk mempelajari dan menghafal Asmaul Husna.

\subsection{Saran}

Berikut adalah beberapa saran yang direkomendasikan untuk melanjutkan penelitian pada pembutan game Asmaul Husna :
1. Game dapat dikembangkan dengan model materi dan soal tentang keagamaan yang dapat menambah pengetahuan anak, seperti makna tiap Asmaul Husna, penarapan Asmaul Husna dalam kegiatan sehari hari, Asmaul Husna dalam AlQuran, dll.

2. Menambahkan fitur animasi singkat sebagai materi mengenai sikap yang mencerminkan Asmaul Husna.

3. Menambahkan fitur materi mendengarkan 99 Asmaul Husna secara langsung tanpa jeda.

4. Game dapat dikembangkan ke dalam versi sistem operasi lain seperti iOS.

\section{DAFTAR PUSTAKA}

Daftar Pustaka ditulis mengikuti format IEEE style berikut:

[1] Basid, P. M, "Rancang Bangun Game Pengenalan Asma'ul Husna Menggunakan Metode MCRN-GENERATOR", S.Kom. Skripsi, Universitas Islam Negeri Maulana Malik Ibrahim Malang, Malang, 2014.

[2] Clark, R. E. "Evaluating the Learning and Motivation Effects of Serious Games. Rosier school of Education Center for Creative Technologie. Internet: http://projects.ict.usc.edu/itgs/talks/Clark_Serious\%20Gam es\%20Evaluation.ppt, 2006 [30 Juni 2020].

[3] Clark, R. E. and Choi, S., "Five design principles for experiments on the effects of animated pedagogical agents", Journal of Educational Computing Research, 2005 .

[4] Clark, D. "Game and e-learning. Sunderland: Caspian Learning”. Internet: www.caspianlearning.co.uk, 2006 [30 Juni 2020].

[5] Dwiyono, "Pengembangan Game Edukasi Sebagai Media Pembelajaran Interaktif Pada Kompetensi Dasar Mendeskripsikan Penggunaan Peralatan Tangan (Hand Tools) Dan Peralatan Bertenaga (Power Tools)", Universitas Negeri Yogyakarta, Yogyakarta, 2017.

[6] Farid, M. et al, "Perancangan Aplikasi Game Pembelajaran Asmaul Husna Berbasis Android." Seminar Nasional Humaniora \& Aplikasi Teknologi Informasi 2017 (SEHATI 2017) ISSN: 2477-0078, 2017.

[7] Masbocah. "Techijau. Retrieved from Urutan Tingkatan Versi Nama Android. Internet: https://techijau.com/urutanversi-nama-android/, 2015 [30 Juni 2020].

[8] Mendikbud RI. Lampiran Permendikbud RI No.024 Tahun 2016. Jakarta: Kementrian Pendidikan dan Kebudayaan Republik Indonesia. 
[9] Murya. Aplikasi dan Android. Jakarta. 2014

[10] Pane, B. et al., "Rancang Bangun Aplikasi Game Edukasi Ragam Budaya Indonesia”, E-Journal Teknik Informatika, Vol 12, No.1 (2017) ISSN : 2301-8364, 2017.

[11] Priyadi, U. et al, "Peningkatan Mutu pembelajaran Taman Pendidikan Al-Quran dengan pembuatan Kurikulum TPA", Jurnal Inovasi dan Kewirausahaan, Vol. 2, No. 3, September 2013.

[12] Santoso dan Nurmalina, R., "Perencanaan dan Pengembangan Aplikasi Absensi Mahasiswa Menggunakan Smart Card Guna Pengembangan Kampus Cerdas (Studi Kasus Politeknik Negeri Tanah Laut)”, Jurnal Integrasi Vol. 9 No. 1, , 84-91 e-ISSN: 2548 - 9828, April 2017.

[13] Trio, R., Wawancara dengan Guru TPA Cabe Rawit Masjid Darussalam Bogor. (N. Nusantara, Interviewer) Bogor, 2020.

[14] Priyadi, U. et al, "Peningkatan Mutu pembelajaran Taman Pendidikan Al-Quran dengan pembuatan Kurikulum TPA”, Jurnal Inovasi dan Kewirausahaan, Vol. 2, No. 3, September 2013.

[15] Urva, G. dan Siregar, H.F. "Pemodelan UML E-Marketing Minyak Goreng”, Jurnal Teknologi dan Sistem Informasi, Volume 1, Nomor 2, hlm 92-101, Maret 2015.

[16] Wijaya, R. F. "Pengertian Edukasi dan Pengertian Game Edukasi." Internet :

https://www.rianfartawijaya.com/2015/02/pengertianedukasi-dan-pengertian-game.html, [9 Juli 2019].

[17] Yustin, J. et al. "Rancang Bangun Aplikasi Game Edukasi Pembelajaran Matematika Menggunakan Construct 2", Jurnal Sistem dan Teknologi Informasi (JUSTIN) Vol. 1, No. 1, 2016.

\section{BIODATA PENULIS}

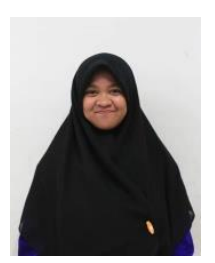

\section{Novaria Nusantara}

Saya bernama Novaria Nusantara. Lahir pada tanggal 1 November 1999 di Bogor. Saya mulai menempuh pendidikan di SD BABAKAN Bogor (2005-2011). Kemudian melanjutkan ke SMP Negeri 2 Bogor (2011-2014). Setelah itu saya menempuh pendidikan di SMA Negeri 7 Bekasi (2014- 2017). Setelah lulus, di tahun 2017 saya melanjutkan pendidikan di Politeknik Negeri Media Kreatif Jakarta, mengambil Program Studi D-3 Multimedia di Jurusan Desain Grafis.

\section{LAMPIRAN}

Wawancara dengan guru salah satu TPA yang berada di Kota Bogor yang dijadikan sample penelitian yaitu TPA Cabe Rawit Masjid Darussalam Bogor.

Narasumber : Rusdi Trio (Kepala Pengajar dan Penanggung Jawab Kegiatan Belajar Mengajar TPA Cabe Rawit Masjid Darussalam)

\begin{tabular}{|c|c|c|}
\hline No & Pertanyaan & Jawaban \\
\hline 1 & $\begin{array}{l}\text { Berapa rentang } \\
\text { usia siswa TPA } \\
\text { Cabe Rawit } \\
\text { Masjid } \\
\text { Darussalam? }\end{array}$ & $\begin{array}{l}\text { Untuk usia anak-anak Cabe Rawit } \\
\text { mulai umur } 5-12 \text { tahun } \\
\text { Setelah itu masuk pra remaja/3G }\end{array}$ \\
\hline 2 & $\begin{array}{l}\text { Apa saja materi } \\
\text { pembelajaran di } \\
\text { TPA Cabe } \\
\text { Rawit Masjid } \\
\text { Darussalam? }\end{array}$ & $\begin{array}{l}\text { Untuk materi pembelajaran antara } \\
\text { lain: } \\
\text { 1. Asmaul Husna } \\
\text { 2. Huruf Arab Dan Hijaiyah } \\
\text { 3. Tata Krama Dan Sopan Santun } \\
\text { 4. Toharoh/Kesucian } \\
\text { 5. Doa Sehari-Hari } \\
\text { 6. Praktek Ibadah } \\
\text { 7. BCM(Bermain,Cerita,Menyanyi) }\end{array}$ \\
\hline 3 & $\begin{array}{l}\text { Mengapa } \\
\text { materi Asmaul } \\
\text { Husna } \\
\text { dijadikan } \\
\text { materi pokok di } \\
\text { TPA Cabe } \\
\text { Rawit Masjid } \\
\text { Darussalam? }\end{array}$ & $\begin{array}{l}\text { Karena keutamaan menghafal } \\
\text { Asmaul Husna telah diterangkan } \\
\text { dalam beberapa hadist barang siapa } \\
\text { yang menghafal } 99 \text { nama Allah, } \\
\text { maka dia akan dimasukkan surga } \\
\text { Kemudian yang kedua karena materi } \\
\text { Asmaul Husna sebagai materi awal } \\
\text { pengenalan bahasa arab yang mudah } \\
\text { ke anak, untuk melanjutkan } \\
\text { pelajaran-pelajaran berikutnya. }\end{array}$ \\
\hline 4 & $\begin{array}{l}\text { Bagaimana } \\
\text { metode } \\
\text { pembelajaran } \\
\text { Asmaul Husna } \\
\text { di TPA Cabe } \\
\text { Rawit Masjid } \\
\text { Darussalam? }\end{array}$ & $\begin{array}{l}\text { Metode yang di pakai adalah guru } \\
\text { membaca dahulu,murid menirukan.. } \\
\text { Baru nanti membaca bersama2 }\end{array}$ \\
\hline 6 & $\begin{array}{lr}\text { Apa } & \text { kendala } \\
\text { yang } & \text { dialami } \\
\text { siswa } & \text { TPA } \\
\text { Cabe } & \text { Rawit }\end{array}$ & $\begin{array}{l}\text { Kendalanya kadang siswa merasa } \\
\text { bosan,atau jenuh dan presentase } \\
\text { kehadiran siswa yang kurang }\end{array}$ \\
\hline
\end{tabular}




\begin{tabular}{|c|c|c|}
\hline & $\begin{array}{l}\text { Masjid } \\
\text { Darussalam } \\
\text { selama proses } \\
\text { pembelajaran? }\end{array}$ & \\
\hline 7 & $\begin{array}{l}\text { Apakah jika } \\
\text { saya membuat } \\
\text { aplikasi game } \\
\text { interaktif } \\
\text { mengenai } \\
\text { Asmaul Husna } \\
\text { akan sangat } \\
\text { membantu } \\
\text { dalam } \\
\text { pembelajaran } \\
\text { Asmaul Husna } \\
\text { di TPA Cabe } \\
\text { Rawit Masjid } \\
\text { Darussalam? }\end{array}$ & $\begin{array}{l}\text { Kalau menurut saya,sangat } \\
\text { membantu } \\
\text { Apalagi sekarang rata-rata } \\
\text { pembelajaran memakai daring,jadi } \\
\text { banyak yang memakai handphone }\end{array}$ \\
\hline
\end{tabular}

